\title{
Investigating the functionality of a ribosome-binding mutant of NAA15 using Saccharomyces cerevisiae
}

Sylvia Varland ${ }^{1,2,3^{*}}$ (D) and Thomas Arnesen 1,2,4

\begin{abstract}
Objective: $\mathrm{N}$-terminal acetylation is a common protein modification that occurs preferentially co-translationally as the substrate $\mathrm{N}$-terminus is emerging from the ribosome. The major $\mathrm{N}$-terminal acetyltransferase complex A (NatA) is estimated to $\mathrm{N}$-terminally acetylate more than $40 \%$ of the human proteome. To form a functional NatA complex the catalytic subunit NAA10 must bind the auxiliary subunit NAA15, which properly folds NAA10 for correct substrate acetylation as well as anchors the entire complex to the ribosome. Mutations in these two genes are associated with various neurodevelopmental disorders in humans. The aim of this study was to investigate the in vivo functionality of a Schizosaccharomyces pombe NAA15 mutant that is known to prevent NatA from associating with ribosomes, but retains NatA-specific activity in vitro.
\end{abstract}

Results: Here, we show that Schizosaccharomyces pombe NatA can functionally replace Saccharomyces cerevisiae NatA. We further demonstrate that the NatA ribosome-binding mutant Naa15 $\triangle N$ K6E is unable to rescue the temperature-sensitive growth phenotype of budding yeast lacking NatA. This finding indicates the in vivo importance of the co-translational nature of NatA-mediated $\mathrm{N}$-terminal acetylation.

Keywords: N-terminal acetyltransferase, NatA, NAA10, NAA15, N-terminal acetylation, Ribosome association, Saccharomyces cerevisiae

\section{Introduction}

$\mathrm{N}$-terminal acetylation is one of the most common protein modifications in eukaryotes, occurring on approximately $80-90 \%$ of all human proteins [1-3]. The functional consequences of attaching an acetyl group to the N-terminus of proteins are diverse. $\mathrm{N}$-terminal acetylation plays a role in regulating protein properties such as folding [4-9], stability [10,11], subcellular localization [12-14], complex formation [15, 16], complex stoichiometry [11] as well as regulating gene expression [17, 18], and actin cytoskeleton dynamics [19]. Moreover, N-terminal acetylation is crucial for normal development of multicellular organisms [20-23]. N-terminal acetylation is carried out by a family of enzymes called $\mathrm{N}$-terminal

\footnotetext{
*Correspondence: sylvia.varland@uib.no

${ }^{1}$ Department of Biological Sciences, University of Bergen, 5006 Bergen, Norway

Full list of author information is available at the end of the article
}

acetyltransferases (NATs). The biological importance of this protein modification is underscored by the fact that dysfunctional NATs are implicated in a variety of developmental disorders and cancers [24-33].

In most cases the NATs anchor to the ribosome where they act on nascent polypeptides as they emerge from the exit tunnel during translation [1]. The enzyme complex NatA is one of the main contributors of N-terminal acetylation $[34,35]$. It acetylates $\mathrm{N}$-termini after the initiator methionine has been cleaved of by methionine aminopeptidase, thus exposing a small $\mathrm{N}$-terminal amino acid (Ser, Ala, Gly, Thr, Val or Cys) [35-37]. The NatA complex is composed of the catalytic subunit Naa10 (Ard1 in yeast) and the auxiliary subunit Naa15 (Nat1) [36, 38-40], both of which are evolutionarily conserved [35]. Structure analysis of the NatA complex from the fission yeast Schizosaccharomyces pombe (Sp) revealed that Naa15 contains 13 conserved tetratricopeptide repeats (TPR) that wraps around Naa10 in a ring-like manner

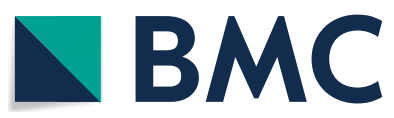

(c) The Author(s) 2018. This article is distributed under the terms of the Creative Commons Attribution 4.0 International License (http://creativecommons.org/licenses/by/4.0/), which permits unrestricted use, distribution, and reproduction in any medium, provided you give appropriate credit to the original author(s) and the source, provide a link to the Creative Commons license, and indicate if changes were made. The Creative Commons Public Domain Dedication waiver (http://creativecommons.org/ publicdomain/zero/1.0/) applies to the data made available in this article, unless otherwise stated. 
[41]. The binding of Naa15 induces an allosteric change in the active site of Naa10, which is essential for catalysis by the NatA complex. Thus, Naa15 is considered a regulatory switch that controls NatA activity. Moreover, Naa15 mediates ribosomal anchoring and interacts with nascent polypeptide [40]. It is thought that Naa15 binds to the general docking site for ribosome-associated factors Rpl25/35 (L23/L29), which is favorable positioned in close proximity to the ribosomal exit tunnel $[42,43]$.

To gain a better understanding for the molecular basis that underlies the interaction between NATs and the ribosome, Magin and colleagues carried out a conservation and electrostatic surface analysis of NatA [44]. Focusing on Naa15, they identified two conserved electropositive regions (EPR) on the surface of NatA that appeared responsible for ribosome interaction. Both regions are situated on the same side of the enzyme and would optimally position the active site of ribosomalbound Naa10 to emerging nascent polypeptides. EPR1 is located within the N-terminal domain of Naa15 and includes the first three TPRs while EPR2 consist of an internal basic $\alpha$-helix that is situated near the C-terminus. By performing mutation analyses of EPR1 and EPR2 the authors generated a SpNaa15 mutant that retained its ability to bind Naa10 and further full enzymatic activity in vitro, but was unable to associate with ribosomes [44]. The functional impact of this ribosome-binding mutant of SpNaa15 in vivo is yet to be investigated.

In this study, we have investigated the functionality of a SpNaa15 mutant that is unable to bind ribosomes. We show, using the budding yeast Saccharomyces cerevisiae (Sc) as a model, that EPR1 and EPR2 contain important functional regions required for NatA activity in vivo. This study highlights the importance of NatA-mediated N-terminal acetylation taking place during protein synthesis.

\section{Main text \\ Methods \\ Yeast strains, plasmid construction, and transformation}

The Saccharomyces cerevisiae strain W303-1A (MATa; ade2-1; ura3-1; his3-11,15; leu2-3,112; trp1-1; can1-100) was used to construct a $S c N a t A \Delta$ strain ( $\operatorname{ard} 1-\triangle \because: L E U 2$; nat1- $\triangle:: k a n M X)$ [35]. Gene deletions were verified by colony PCR using primers ARD1-176 F (5'-GTCTTTATT GATCTCTAGGCTCAATCC-3') with ARD1 848 R (5'CCTTACTATTCATGCTCACACAATTC-3') and NAT1 -213 F (5'-CCAAATTGCATGACCTTGCTAATGAGG$3^{\prime}$ ) with NAT1 2763 R (5'-GGAAAGCAAGAATTTTGG CAAGAAAAGG-3'). The $S$. cerevisiae expression vector pBEVY-U-SpNatA was generated by inserting a C-terminally truncated version of SpNAA10-V5 (residues 1-156 out of 177 total residues) after the ADH1 promoter using the $X m a \mathrm{I} / E c o$ RI sites and full-length HA-SpNAA15 (residues 1-729) after the GPD promoter using the XbaI/SalI sites. pBEVY-U-SpNatA was used to construct pBEVYU-SpNatA- $\Delta$ N-K6E （p.SpNaa15 aa1_109del, K605E, K606E, K609E, K610E, K612E, K613E) in a three-step process using the Q5 site-directed mutagenesis kit (NEB, \#E0554S) with the following mutagenic primers: (i) SpNAA15 aa1_109 del F (5'-AACAACTCGAGTCTT TTGCG-3') with SpNAA15 aa1_109 del R (5'-AAGGGC CTGTACAGCGTAAT-3'), (ii) SpNAA15 aa605_613del F (5'-GACCTTAGTAAACGATTGGAACG-3') with SpNAA15 aa605_613del R (5'-TTCCTCTTCTTCATT TATTTCTCCAC-3'), and (iii) SpNAA15 aa605_613ins F (5'-agaactcgaagaaGACCTTAGTAAACGATTGG-3') with SpNAA15 aa605_613ins R (5'-tcataaatttcttcTTC CTCTTCTTCATTTATTTCTC-3'). Mutants were confirmed by sequencing. pBEVY-U-SpNatA and pBEVYU-SpNatA- $\Delta \mathrm{N}-\mathrm{K} 6 \mathrm{E}$ were transformed into the ScNatA $\Delta$ strain using standard yeast techniques [45]. In addition, the wild-type strain and the ScNatA $\Delta$ strain were transformed with empty pBEVY-U plasmid. Transformants were selected and maintained on SD-Ura agar [0.67\% $(\mathrm{w} / \mathrm{v})$ yeast nitrogen base without amino acids, $0.2 \%(\mathrm{w} / \mathrm{v})$ yeast drop-out mix without uracil, $2 \%(\mathrm{w} / \mathrm{v})$ glucose, and $2 \%(\mathrm{w} / \mathrm{v})$ agar $]$.

\section{Immunoblotting}

Yeast whole-cell protein extracts were prepared by alkaline treatment as previously described [46]. Protein extracts were separated by SDS-PAGE and analyzed by immunoblotting. The immunoblots were probed with rabbit polyclonal anti-HA tag (1:10,000, Abcam, ab9110), mouse monoclonal anti-V5 tag (1:10,000, Invitrogen, \#R960-25), and rabbit polyclonal anti-Zwf1 (1:15,000, Sigma, A9521). HRP-conjugated rabbit or mouse antigoat IgG were used as secondary antibodies $(1: 10,000$, Bio-Rad, \#1706515 and \#1706516). All antibodies were diluted in 1X TBS containing 5\% nonfat dry milk (w/v) and $0.05 \%$ Tween-20. The immunoblots were developed using SuperSignal West Femto Maximum Sensitivity Substrate (Thermo Scientific, \#34095) followed by detection and imaging using VersaDoc MP 5000 from Bio-Rad.

\section{Yeast growth assay}

Wild-type and ScNatA $\Delta$ yeast strains were grown in SD-Ura at $30{ }^{\circ} \mathrm{C}$ to early log phase $\left(\mathrm{OD}_{600} 0.8-1.0\right)$ and adjusted to $1 \mathrm{OD}_{600} / \mathrm{ml}$. Ten-fold serial dilutions with sterile milliQ water were spotted $(2 \mu \mathrm{l})$ onto YPD [1\% $(\mathrm{w} / \mathrm{v})$ yeast extract, $2 \%(\mathrm{w} / \mathrm{v})$ peptone $(\mathrm{w} / \mathrm{v}), 0.012 \%(\mathrm{w} / \mathrm{v})$ 
adenine, 2\% (w/v) glucose, and 2\% (w/v) agar] and SDUra agar $[0.67 \%(\mathrm{w} / \mathrm{v})$ yeast nitrogen base without amino acids, $0.2 \%(\mathrm{w} / \mathrm{v})$ yeast drop-out mix without uracil, $2 \%$ $(\mathrm{w} / \mathrm{v})$ glucose, and $2 \%(\mathrm{w} / \mathrm{v})$ agar]. The plates were incubated at 30 or $38^{\circ} \mathrm{C}$ for 2 days and imaged with spImager from S\&P Robotics.

\section{Results and discussion}

Naa15 constitutes the auxiliary part of the NatA complex and regulates its activity in a dual manner: by anchoring the catalytic subunit Naa10 to the ribosome so that nascent polypeptide chains are presented to Naa10 which in turn acetylates the $\mathrm{N}$-terminal amino group, and secondly by modulating the catalytic site of Naa10 to match the broad spectrum of its in vivo substrates [40]. Both Naa10 and Naa15 are highly conserved in eukaryotes [35]. The human Naa15 protein share $46.6 \%$ and $43.4 \%$ sequence similarity with its $S$. pombe and $S$. cerevisiae homologues, respectively, with largest variation at the C-terminus (Fig. 1). The sequence similarity between SpNaa15 and ScNaa15 is $44.5 \%$. Using the structure of SpNatA (Fig. 2a) [41], Magin et al. [44] identified two conserved electropositive regions (EPR) in Naa15, an $\mathrm{N}$-terminal region and an internal basic helix near the C-terminus, that could potentially facilitate the interaction between NatA and the ribosomes. Moreover, they generated a series of mutants targeting these two regions. They showed, using an in vitro N-terminal acetylation assay, that the NatA variant SpNaa15 $\Delta \mathrm{N}$ K6E (p. $\Delta 1-109$, K605E, K606E, K609E, K610E, K612E, K613E) (Fig. 2b) was enzymatically active towards the serine-starting peptide SESS-(corresponding to the $\mathrm{N}$-terminus of HMGA1), representing a classical NatA substrate. They also revealed with NatA-ribosome co-sedimentation and gel filtration analyses that the $\triangle \mathrm{N}$ K6E mutant was unable to bind ribosomes.

The NatA complex is conserved from yeast to human, as shown by complementation of growth phenotypes and partial rescue of the N-terminal acetylome [35]. With this in mind, we developed a simple functional assay for NatA mutations that is based on the temperature-sensitive growth phenotype of budding yeast lacking NatA $[35,36,47,48]$. To functionally assess the SpNaa15 $\Delta \mathrm{N}$ K6E mutant, we transformed a $\operatorname{ard} 1 \Delta /$ nat1 $\Delta$ double deletion strain $(S c N a t A \Delta)$ (Fig. 3a) with a bidirectional expression vector encoding either SpNatA wild-type or SpNatA $\triangle \mathrm{N}$ K6E (schematic of the constructs is shown in Fig. 2c). SpNatA expression in the ScNatA $\Delta$ deletion strain was confirmed by immunoblot analysis using antiHA and anti-V5 to detect HA-SpNaa15 and SpNaa10-V5, respectively (Fig. 3b). As expected the SpNaa15 $\Delta \mathrm{N} \mathrm{K6E}$ variant had a lower molecular weight than full-length SpNa15 (HA-SpNaa15, 746 amino acids, $85.5 \mathrm{kDa}$ ). We also observed a non-specific band around $80 \mathrm{kDa}$, which is caused by the secondary antibody used.

We next performed a yeast growth assay where serial dilutions of wild-type (W303-1A) + empty vector, ScNatA $\Delta+$ empty vector, ScNatA $\Delta+$ SpNatA, or ScNatA $\Delta+$ SpNatA $\Delta \mathrm{N}$ K6E strains was spotted onto YPD and selective SD-Ura media. In agreement with previous studies, we observed reduced growth of the NatA knockout strain at elevated temperatures (Fig. 3c). Moreover, overexpression of the SpNatA complex rescued the growth defect of ScNatA $\Delta$ mutant cells. Consequently, SpNatA can functionally replace ScNatA, suggesting that the NatA complex is structurally very similar in the two yeast species. This observation was made on both YPD and SD-Ura growth media. Thus, ScNatA $\Delta$ mutant cells are able to retain the SpNatA plasmid even in the absence of selection due to the high selective pressure on cell viability. Overexpression of the SpNatA $\Delta \mathrm{N}$ K6E mutant, however, failed to rescue the temperature-sensitive growth phenotype of $S c N a t A \Delta$. Although the SpNatA $\Delta \mathrm{N}$ K6E variant was enzymatically active in vitro [44], this finding indicates that ribosome binding is essential for normal NatA function in vivo. Favorable electrostatic interactions appear to be a common feature for the interaction between molecular chaperones involved in co-translational folding and the ribosome $[43,44]$. The NatA complex associates with the ribosome in a saltsensitive manner, indicating an association mediated by ionic interactions $[40,44,49]$. Intriguingly, both the positively charged $\mathrm{N}$-terminal region and the positively charged internal helix in Naa15 are situated on the same side of NatA and facing the ribosomal exit tunnel [44]. Thus, modifications within these two regions may interfere with NatA's ability to interact with the ribosome and perform co-translational $\mathrm{N}$-terminal acetylation by affecting the orientation and the electrostatic potential. The binding to Naa10 and NAT-activity were not affected in vitro [44]. Nevertheless, overexpression of SpNatA $\triangle \mathrm{N}$ K6E seems to confer ScNatAD cells with slightly better growth at $38{ }^{\circ} \mathrm{C}$ compared to empty vector, suggesting that this mutant may have a small residual capacity to acetylate selected substrates controlling this phenotype. It may either mean that the mutant has retained a weak ability to associate with ribosomes, or has a residual capacity to perform post-translational $\mathrm{N}$-terminal acetylation. 
61 KKEEAYELVRRGLR - - - NDLKSHVCWHVYGLLQRSDKKYDEA I KCYRNAL KWDKDNLQ ILRDLSLLQIQM 127 ScNaa15 59 NTKEGYDNVRLGLR - - - NDVGSGVCWH I FGL I SRADKDYVQAAKCY I NAHKLEKNNSSLLRDLALLQSQL 125 HsNaa15 128 RDLEGYRETRYQLLQLRPAQRASWIGYA I AYHLLEDYEMAAK ILEEFRKTQQTS - PDKVDYEYSELLLYQ 196 SpNaa15 126 RQYKALADTRNALLQDNPGVRANWSALAVAQFLRGEYASAYKIVDAFESTINQG-VPVDTQEESEAMLFM 194 ScNaa15 139 GDFKNAL VSRKKYWEAFLGYRANWTSLAVAQDVNGERQQA INTLSQFEKLAEGK I SDSEKYEHSECLMYK 208

HsNaa15 197 NQVLREA - - - - GL GREALEHLCTYEKQ I CDKL A VEETKGELLLQL CRLEDAADVYRGLQERNPENWAYY 261 SpNaa15 195 NL V I L KK - - - - DGVEDAYKHLL S I EKKVLDRVAFLETRAEYELYLSKMEEAKST I YLLLDRNPDNHQYY 259 ScNaa15 209 NDIMYKAASDNQDKLQNVLKHLNDI EPCVFDKFGLLERKAT I YMKLGQL KDAS I VYRTL I KRNPDNFKYY 278

HsNaa15 262 KGLEKALKPA - . . . . NMLERL K I YEEAWTKYPRGL VPRRLPLNFLSGE - KFKECLDKFLRMNFSKGCP 323 SpNaa15 260 YNLQRAYGYEDASGKVLDSAEWL NL YSQLAKRYPKSECPTRLPLEKLEGD-EFLTHVDLYLRKKLKRG I P 328 ScNaa15 279 KLLEVSLGIQGDN- - - - KL KKALYGKLEQFYPRCEPPKFIPLTFLQDKEELSKKLREYVLPQLERGVP 342

HsNaa15 324 PVFNTLRSLYKDKEK - - VA I I EELVVGYETSLKSCRLFNPNDD-GKEEPPTTLLWVQYYLAQHYDK I GQP 390 SpNaa15 329 SVFVDVKSLYKDTKK- - CKVVEDLVSKYASSLSTTNKFSEDDDNSQ IE IPTTLLWTYYFLAQHFDHVGEL 396 ScNaa15 343 ATFSNVKPLYQRRKSKVSPLLEKIVLDYLSGLDP . . . . . . . - TQDPIPF IWTNYYLSQHFLFLKDF 400

HsNaa15 391 S I ALEY I NTA I ESTPTL I ELFL VKAK I YKHAGN I KEAARWMDEAQALDTADRF I NSKCAKYML KANL I KE 460 SpNaa15 397 EKAEKYVDLA I DHTPTLVELFMTKAR I SKHKGELQTAME I MDHARKLDLQDRF I NGKCAKYMLRNDENEL 466 ScNaa15 401 PKAQEY I DAALDHTPTL VEFY I L KAR I L KHLGLMDTAAG I LEEGRLDLQDRF I NCKTVKYFLRANNI DK 470

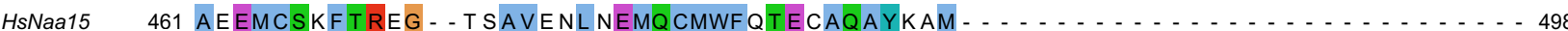
SpNaa15 467 A AKT VSLFTRNEA VGGA VGDL ADMQCLWYMLEDGKSFARQ . . . . . . . . . . . . . . . . . . 506 ScNaa15 471 AVEVASLFTKNDDSVNG I KDL HLVEASWF I VEQAEAYYRLYLDRKKKLDDLASLKKEVESDKSEQ I ANDI 540

HsNaa15 $499 \ldots \ldots$ - . . NKFGEALKKCHE I ERHF I E I T DDQF DFHTYCMRK I TLRSYVDLLKLEDVLRQHPFYFKAARI 560 SpNaa15 $507 \ldots \ldots$. . . KKFALALKRF STVFK I F DTWADDQF DFHFFAFRKGSLRTYLDLMSWEDSVYDDPSFREAAQG 568 ScNaa15 541 KENQWL VRKYKGLAL KRFNA I PKF YKQFEDDQL DF HSYCMRKGTPRAYLEMLEWGKAL YTKPMYVRAMKE 610

HsNaa15 561 A I E I YLKLHDNPL TDENKEHEADTANMSDK - - - - EL KKLRNKQRRAQKKAQ IEEEKKNAEKEKQQRNQK 625 SpNaa15 569 S I E I YFALF DLPFAKYSPKLP - DFEKL SSGE I NEEE EKK I YKKLKKD - - - - L SKRLERAEKLKEADKS - 631 ScNaa15 611 ASKLYFQMHDDRLKRKSDSLDENSDEIQNNGQNSSSQKKKAKKE - - - - A AAMNKRK - - - - - - - - ET 664

HsNaa15 626 KKKDDDDEE I GGPKEEL I PEKL AKVETPLEEA I K - FL TPLKNLVKNK IETHLFAFE I YFRKEKFLLMLQS 694 SpNaa15 632 RAKSEDGM - PVKYDEDPLGENLVATSEPLKEAQK - CLEKLLPYGDKNPSAYILAAQLYTRLKNF - - - - - 693 ScNaa15 665 EAK-SVAAYPSDQDNDVFGEKL I ETSTPMEDFATEFYNNYSMQVREDERDY I LDFEFNYRI GKLALCFAS 733

HsNaa15 695 VKRAFA - I DSSHPWL HECM I RLFNTAVCESKDLSDTVRTVLKQEMNRLFGATNPKN - . . . - . - F _ 750

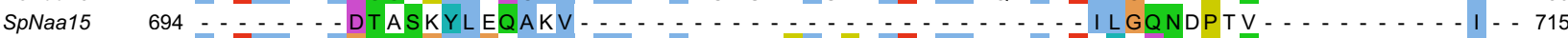
ScNaa15 734 LNKFAKRFGTTSGLFGSMA I VLLH-ATRNDTPFDP I LKKVVTKSLEKEYSENFPLNE I SNNSFDWLNFYQ 802

HsNaa15 $751 \ldots \ldots$ - . - NETFLKRNSDSLPHRL SAAKM - - - - VYYLDPSSQKRA IELATTLDESLTNRNLQT CMEVL 806

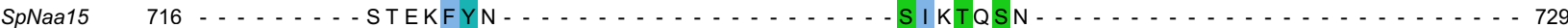
ScNaa15 803 EKFGKND I NGLLFLYRYRDDVPI GSSNLKEMI I SSLSPLEPHSQNEILQ . . . . . . . . . . . . 851 HsNaa15 807 EAL YDGSLGDCKEAAE I YRANCHKLFPYALAFMPPGYEEDMK I TVNGDSSAEAEELANE I 866 SpNaa15 ScNaa15 $\ldots \ldots \ldots \ldots \ldots \ldots \ldots \ldots \ldots$

Fig. 1 Multiple sequence alignment of Naa15 from H. sapiens (Hs), S. pombe (Sp), and S. cerevisiae (Sc). The alignment was generated in Clustal Omega [51] and edited in Jalview [52]. The N-terminal region (EPR1) and the internal basic helix (EPR2) are indicated in blue. Light blue color indicates hydrophobic residues, red indicates basic residues, magenta indicates acidic residues, green indicates polar residues, pink indicates cysteines, orange indicates glycines, yellow indicates prolines, and cyan indicates aromatic residues

In conclusion, this yeast model complements the findings from the Magin study and supports the notion that EPR1 and EPR2 of the ribosome binding subunit Naa15 plays important structural role for correct and efficient NatA activity during protein synthesis. Mutation in these electropositive regions could have deleterious effects and, as suggested by Magin et al. could be 


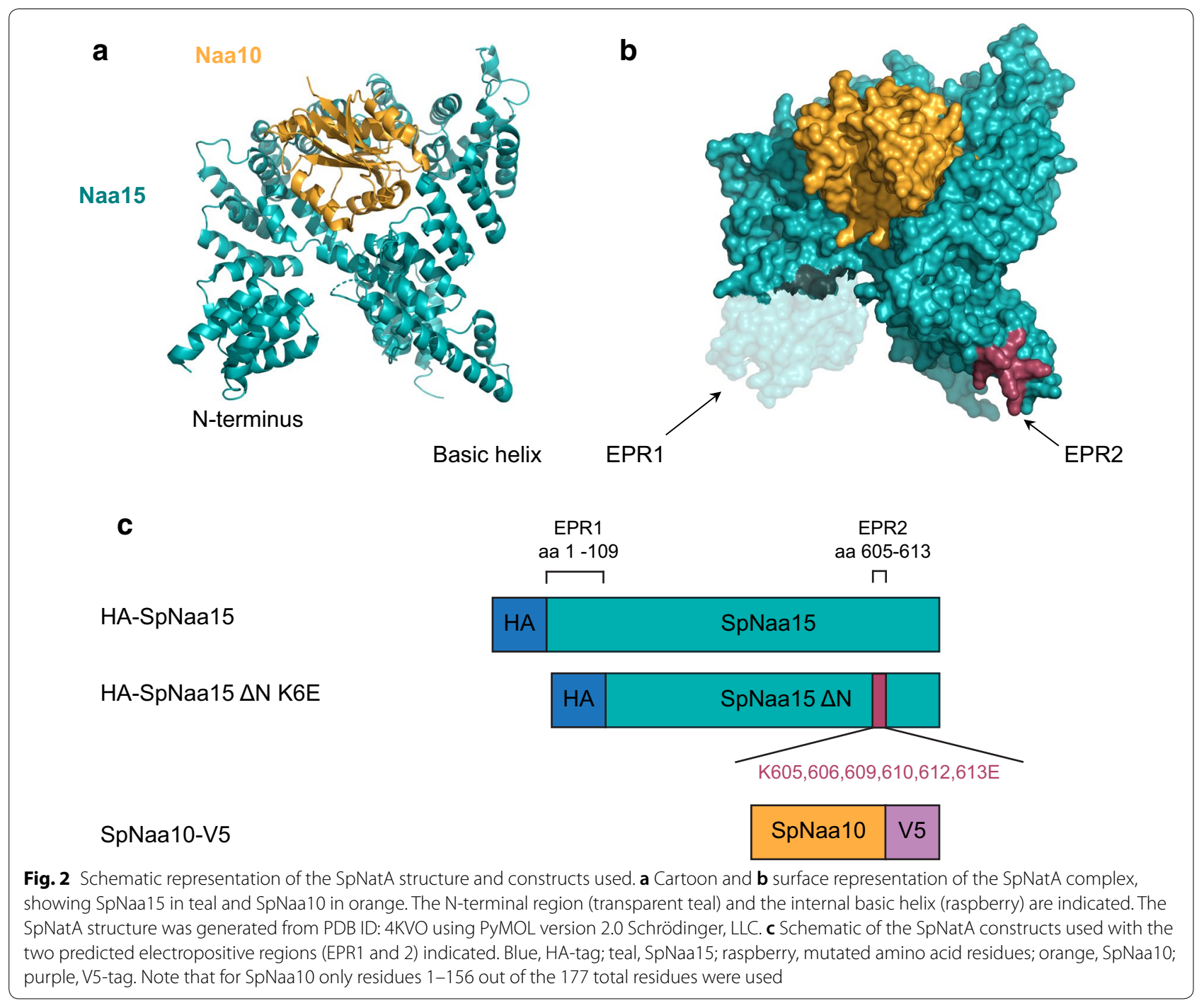

used for therapeutic targeting of NatA activity by modifying ribosome binding.

\section{Limitations}

- We acknowledge that this study only provide preliminary insights into the interaction between NatA and the ribosome and that it does not exclude the possibility that other regions on the NatA surface or binding factors are important for ribosome binding. For example, the NatA complex also associates with Naa50 [40] and in multicellular eukaryotes the chaperone-like protein HYPK (Huntingtin-interacting protein K) [50].
- We focused on SpNatA $\Delta \mathrm{N}$ K6E since Magin et al. [44] showed that this mutant displayed the most severe ribosomal pulldown effect.

- Incorporation of a V5-tag C-terminal of SpNaa10 and a HA-tag N-terminal of SpNaa15 may affect SpNatA complex formation, ribosome binding, and/ or enzymatic activity, but wild-type and mutant SpNaa15 were assayed and compared with identical tags.

- We have not performed any SpNatA-ribosome pulldown experiments using yeast lysates. 

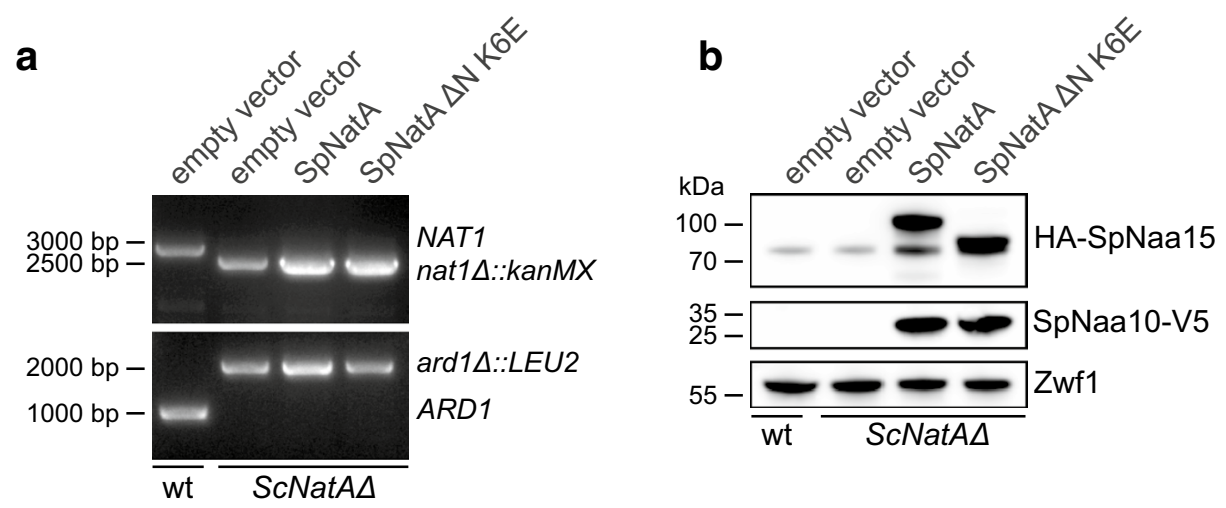

C

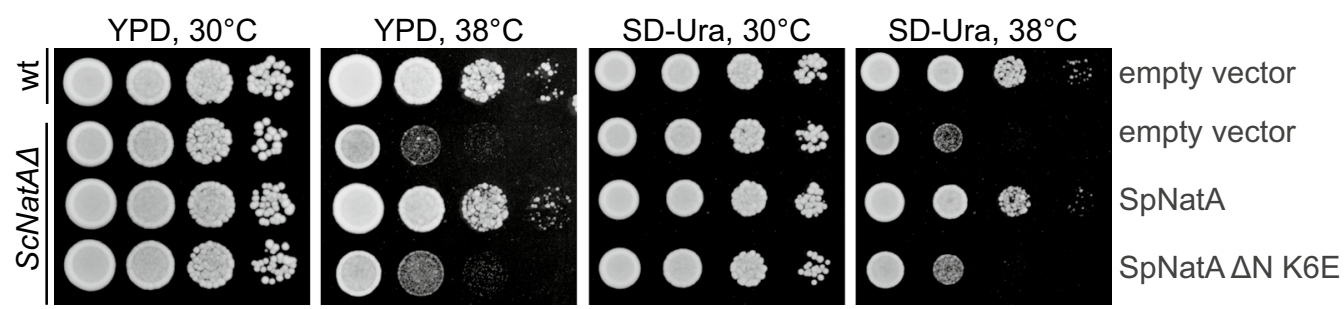

Fig. $3 \mathrm{SpNatA} \triangle \mathrm{N}$-K6E does not rescue growth of $S C N a t A \triangle$ cells at high temperature. a Confirming gene disruption of ARD1 and NAT1 in a SCNatA $\triangle$ strain by colony PCR using ARD1 and NAT1 primers. ARD1-specific PCR product 1024 bp (ARD1 $717 \mathrm{bp}+$ gene-specific sequence $307 \mathrm{bp}$ ). NAT1-specific PCR product 2976 bp (NAT1 2565 bp + gene-specific sequence 411 bp). b SpNatA expression was confirmed by immunoblot analyses using anti-HA (to detect HA-SpNaa15) and anti-V5 (to detect SpNaa10-V5). Anti-Zwf1 served as loading control. c Wild-type (W303-1A) and ScNatA $\triangle$ yeast cells transformed with empty pBEVY plasmid, wild-type SpNatA, or SpNatA $\triangle N$-K6E were grown to early log-phase in SD-Ura medium. Ten-fold serial dilutions were spotted onto YPD and SD-Ura agar plates and incubated for 2 days at 30 or $38^{\circ} \mathrm{C}$. wt; wild-type

\section{Abbreviations}

EPR: electropositive region; Naa: Na-terminal acetyltransferase; NAT: N-terminal acetyltransferase; Sc: Saccharomyces cerevisiae; Sp: Schizosaccharomyces pombe; TPR: tetratricopeptide repeats.

\section{Authors' contributions}

SV performed experiments. SV and TA conceived and designed the experiments, analyzed the data and wrote the paper. Both authors read and approved the final manuscript.

\section{Author details}

${ }^{1}$ Department of Biological Sciences, University of Bergen, 5006 Bergen, Norway. ${ }^{2}$ Department of Biomedicine, University of Bergen, 5009 Bergen, Norway. ${ }^{3}$ Donnelly Centre for Cellular and Biomolecular Research, University of Toronto, Toronto, ON M5S 3E1, Canada. ${ }^{4}$ Department of Surgery, Haukeland University Hospital, 5021 Bergen, Norway.

\section{Acknowledgements}

Prof. Ronen Marmorstein (University of Pennsylvania, USA) and Dr. Robert Magin are thanked for initial discussions on mutants of NAA15 preventing ribosome-binding of NatA.

\section{Competing interests}

The authors declare that they have no competing interests.

\section{Availability of data and materials}

Data and materials available upon request.

\section{Consent for publication}

Not applicable.

\section{Ethics approval and consent to participate} Not applicable.

\section{Funding}

This work was supported by the Research Council of Norway through a FRIPRO Mobility Grant 261981 (S.V.) which is co-funded by the European Union's Seventh Framework Programme under Marie Curie grant agreement no 608695. The Research Council of Norway Grants 230865 and 249843 (T.A.), the Norwegian Cancer Society (T.A.), the Bergen Research Foundation (T.A.), and the Norwegian Health Authorities of Western Norway Project 912176 (T.A.).

\section{Publisher's Note}

Springer Nature remains neutral with regard to jurisdictional claims in published maps and institutional affiliations.

Received: 7 May 2018 Accepted: 18 June 2018

Published online: 22 June 2018

\section{References}

1. Aksnes H, Drazic A, Marie M, Arnesen T. First things first: vital protein marks by N-terminal acetyltransferases. Trends Biochem Sci. 2016:41(9):746-60

2. Drazic A, Myklebust LM, Ree R, Arnesen T. The world of protein acetylation. Biochim Biophys Acta. 2016;1864(10):1372-401.

3. Aksnes H, Van Damme P, Goris M, Starheim KK, Marie M, Stove SI, Hoel C, Kalvik TV, Hole K, Glomnes N, et al. An organellar nalpha-acetyltransferase, naa60, acetylates cytosolic $\mathrm{N}$ termini of transmembrane proteins and maintains Golgi integrity. Cell Rep. 2015;10(8):1362-74. 
4. Holmes WM, Mannakee BK, Gutenkunst RN, Serio TR. Loss of aminoterminal acetylation suppresses a prion phenotype by modulating global protein folding. Nat Commun. 2014;5:4383.

5. Trexler AJ, Rhoades E. N-terminal acetylation is critical for forming a-helical oligomer of a-synuclein. Protein Sci. 2012;21(5):601-5.

6. Bartels T, Kim NC, Luth ES, Selkoe DJ. N-alpha-acetylation of alphasynuclein increases its helical folding propensity, GM1 binding specificity and resistance to aggregation. PLoS ONE. 2014;9(7):e103727.

7. Dikiy I, Eliezer D. N-terminal acetylation stabilizes $\mathrm{N}$-terminal helicity in lipid- and micelle-bound alpha-synuclein and increases its affinity for physiological membranes. J Biol Chem. 2014;289(6):3652-65.

8. Kang L, Moriarty GM, Woods LA, Ashcroft AE, Radford SE, Baum J. $\mathrm{N}$-terminal acetylation of alpha-synuclein induces increased transient helical propensity and decreased aggregation rates in the intrinsically disordered monomer. Protein Sci. 2012;21(7):911-7.

9. Permyakov SE, Vologzhannikova AA, Emelyanenko VI, Knyazeva EL, Kazakov AS, Lapteva YS, Permyakova ME, Zhadan AP, Permyakov EA. The impact of alpha- $N$-acetylation on structural and functional status of parvalbumin. Cell Calcium. 2012;52(5):366-76.

10. Hwang CS, Shemorry A, Varshavsky A. N-terminal acetylation of cellular proteins creates specific degradation signals. Science. 2010;327(5968):973-7.

11. Shemorry A, Hwang CS, Varshavsky A. Control of protein quality and stoichiometries by $\mathrm{N}$-terminal acetylation and the $\mathrm{N}$-end rule pathway. Mol Cell. 2013;50(4):540-51.

12. Setty SRG, Strochlic TI, Tong AHY, Boone C, Burd CG. Golgi targeting of ARF-like GTPase Arl3p requires its $N$-alpha-acetylation and the integral membrane protein Sys 1 p. Nat Cell Biol. 2004;6(5):414

13. Behnia R, Panic B, Whyte JR, Munro S. Targeting of the Arf-like GTPase Arl3p to the Golgi requires N-terminal acetylation and the membrane protein Sys1p. Nat Cell Biol. 2004;6(5):405-13.

14. Murthi A, Hopper AK. Genome-wide screen for inner nuclear membrane protein targeting in Saccharomyces cerevisiae: roles for $\mathrm{N}$-acetylation and an integral membrane protein. Genetics. 2005;170(4):1553-60.

15. Scott DC, Monda JK, Bennett EJ, Harper JW, Schulman BA. N-terminal acetylation acts as an avidity enhancer within an interconnected multiprotein complex. Science. 2011;334(6056):674-8

16. Monda JK, Scott DC, Miller DJ, Lydeard J, King D, Harper JW, Bennett EJ, Schulman BA. Structural conservation of distinctive N-terminal acetylation-dependent interactions across a family of mammalian NEDD 8 ligation enzymes. Structure. 2013;21(1):42-53.

17. Schiza V, Molina-Serrano D, Kyriakou D, Hadjiantoniou A, Kirmizis A. $\mathrm{N}$-alpha-terminal acetylation of histone $\mathrm{H} 4$ regulates arginine methylation and ribosomal DNA silencing. PLoS Genet. 2013;9(9):e1003805.

18. Pavlou D, Kirmizis A. Depletion of histone N-terminal-acetyltransferase Naa40 induces p53-independent apoptosis in colorectal cancer cells via the mitochondrial pathway. Apoptosis. 2016;21(3):298-311.

19. Drazic A, Aksnes H, Marie M, Boczkowska M, Varland S, Timmerman E, Foyn $\mathrm{H}$, Glomnes N, Rebowski G, Impens F, et al. NAA80 is actin's $\mathrm{N}$-terminal acetyltransferase and regulates cytoskeleton assembly and cell motility. Proc Natl Acad Sci USA. 2018;115(17):4399-404.

20. Chen D, Zhang JL, Minnerly J, Kaul T, Riddle DL, Jia KL. daf-31 encodes the catalytic subunit of $\mathrm{N}$ alpha-acetyltransferase that regulates caenorhabditis elegans development, metabolism and adult lifespan. PLoS Genet. 2014;10(10):e1004699.

21. Ree R, Myklebust LM, Thiel P, Foyn H, Fladmark KE, Arnesen T. The N-terminal acetyltransferase Naa10 is essential for zebrafish development. Biosci Rep. 2015:35:e00249.

22. Silva RD, Martinho RG. Developmental roles of protein N-terminal acetylation. Proteomics. 2015;15(14):2402-9.

23. Linster E, Stephan I, Bienvenut WV, Maple-Grodem J, Myklebust LM, Huber M, Reichelt M, Sticht C, Moller SG, Meinnel T, et al. Downregulation of $\mathrm{N}$-terminal acetylation triggers $\mathrm{ABA}$-mediated drought responses in Arabidopsis. Nat Commun. 2015;6:7640.

24. Rope AF, Wang K, Evjenth R, Xing J, Johnston JJ, Swensen JJ, Johnson WE, Moore B, Huff CD, Bird LM, et al. Using VAAST to identify an X-linked disorder resulting in lethality in male infants due to $\mathrm{N}$-terminal acetyltransferase deficiency. Am J Hum Genet. 2011;89(1):28-43.

25. Rauch A, Wieczorek D, Graf E, Wieland T, Endele S, Schwarzmayr T, Albrecht B, Bartholdi D, Beygo J, Di Donato N, et al. Range of genetic mutations associated with severe non-syndromic sporadic intellectual disability: an exome sequencing study. Lancet. 2012;380(9854):1674-82.

26. Esmailpour T, Riazifar H, Liu LN, Donkervoort S, Huang VH, Madaan S, Shoucri BM, Busch A, Wu J, Towbin A, et al. A splice donor mutation in NAA10 results in the dysregulation of the retinoic acid signalling pathway and causes Lenz microphthalmia syndrome. J Med Genet. 2014;51(3):185-96.

27. Casey JP, Stove SI, McGorrian C, Galvin J, Blenski M, Dunne A, Ennis S, Brett F, King MD, Arnesen T, et al. NAA10 mutation causing a novel intellectual disability syndrome with Long QT due to N-terminal acetyltransferase impairment. Sci Rep. 2015;5:16022.

28. Popp B, Stove SI, Endele S, Myklebust LM, Hoyer J, Sticht H, Azzarello-Burri S, Rauch A, Arnesen T, Reis A. De novo missense mutations in the NAA10 gene cause severe non-syndromic developmental delay in males and females. Eur J Hum Genet. 2015;23(5):602-9.

29. Myklebust LM, Van Damme P, Stove SI, Dorfel MJ, Abboud A, Kalvik TV, Grauffel C, Jonckheere V, Wu Y, Swensen J, et al. Biochemical and cellular analysis of Ogden syndrome reveals downstream Nt-acetylation defects. Hum Mol Genet. 2015;24(7):1956-76.

30. Sidhu M, Brady L, Tarnopolsky M, Ronen GM. Clinical manifestations associated with the N-terminal-acetyltransferase NAA10 gene mutation in a girl: Ogden syndrome. Pediatr Neurol. 2017;76:82-5.

31. McTiernan N, Stove SI, Aukrust I, Marli MT, Myklebust LM, Houge G, Arnesen T. NAA10 dysfunction with normal NatA-complex activity in a girl with non-syndromic ID and a de novo NAA10 p. (V111G) variant-a case report. BMC Med Genet. 2018;19(1):47.

32. Cheng H, Dharmadhikari AV, Varland S, Ma N, Domingo D, Kleyner R, Rope AF, Yoon M, Stray-Pedersen A, Posey JE, et al. Truncating variants in NAA15 are associated with variable levels of intellectual disability, autism spectrum disorder, and congenital anomalies. Am J Hum Genet. 2018;102(5):985-94.

33. Støve SI, Blenski M, Stray-Pedersen A, Wierenga KJ, Jhangiani SN, Akdemir ZC, Crawford D, McTiernan N, Myklebust LM, Purcarin G, et al. A novel NAA10 variant with impaired acetyltransferase activity causes developmental delay, intellectual disability and hypertrophic cardiomyopathy. Eur J Hum Genet. 2018. https://doi.org/10.1038/s41431-018-0136-0.

34. Van Damme P, Hole K, Pimenta-Marques A, Helsens K, Vandekerckhove J, Martinho RG, Gevaert K, Arnesen T. NatF contributes to an evolutionary shift in protein $\mathrm{N}$-terminal acetylation and is important for normal chromosome segregation. PLoS Genet. 2011;7(7):e1002169.

35. Arnesen T, Van Damme P, Polevoda B, Helsens K, Evjenth R, Colaert N, Varhaug JE, Vandekerckhove J, Lillehaug JR, Sherman F, et al. Proteomics analyses reveal the evolutionary conservation and divergence of $\mathrm{N}$-terminal acetyltransferases from yeast and humans. Proc Natl Acad Sci USA. 2009;106(20):8157-62.

36. Mullen JR, Kayne PS, Moerschell RP, Tsunasawa S, Gribskov M, Colavitoshepanski M, Grunstein M, Sherman F, Sternglanz R. Identification and characterization of genes and mutants for an N-terminal acetyltransferase from yeast. EMBO J. 1989;8(7):2067-75.

37. Polevoda B, Norbeck J, Takakura H, Blomberg A, Sherman F. Identification and specificities of $\mathrm{N}$-terminal acetyltransferases from Saccharomyces cerevisiae. EMBO J. 1999;18(21):6155-68.

38. Park EC, Szostak JW. Ard1 and Nat1 proteins form a complex that has N-terminal acetyltransferase activity. EMBO J. 1992;11(6):2087-93.

39. Arnesen T, Anderson D, Baldersheim C, Lanotte M, Varhaug JE, Lillehaug JR. Identification and characterization of the human ARD1-NATH protein acetyltransferase complex. Biochem J. 2005;386(3):433-43.

40. Gautschi M, Just S, Mun A, Ross S, Rucknagel P, Dubaquie Y, EhrenhoferMurray A, Rospert S. The yeast N(alpha)-acetyltransferase NatA is quantitatively anchored to the ribosome and interacts with nascent polypeptides. Mol Cell Biol. 2003;23(20):7403-14

41. Liszczak G, Goldberg JM, Foyn H, Petersson EJ, Arnesen T, Marmorstein R. Molecular basis for N-terminal acetylation by the heterodimeric NatA complex. Nat Struct Mol Biol. 2013;20(9):1098.

42. Polevoda B, Brown S, Cardillo TS, Rigby S, Sherman F. Yeast N-alphaterminal acetyltransferases are associated with ribosomes. J Cell Biochem. 2008;103(2):492-508

43. Kramer G, Boehringer D, Ban N, Bukau B. The ribosome as a platform for co-translational processing, folding and targeting of newly synthesized proteins. Nat Struct Mol Biol. 2009;16(6):589-97. 
44. Magin RS, Deng S, Zhang H, Cooperman B, Marmorstein R. Probing the interaction between NatA and the ribosome for co-translational protein acetylation. PLoS ONE. 2017;12(10):e0186278.

45. Gietz RD, Schiestl RH. Large-scale high-efficiency yeast transformation using the LiAc/SS carrier DNA/PEG method. Nat Protoc. 2007;2(1):38-41.

46. Goris M, Magin RS, Foyn H, Myklebust LM, Varland S, Ree R, Drazic A, Bhambra P, Stove SI, Baumann M, et al. Structural determinants and cellular environment define processed actin as the sole substrate of the N-terminal acetyltransferase NAA80. Proc Natl Acad Sci USA. 2018;115(17):4405-10.

47. Whiteway M, Szostak JW. The ARD1 gene of yeast functions in the switch between the mitotic cell cycle and alternative developmental pathways. Cell. 1985:43(2 Pt 1):483-92.

48. Lee FJS, Lin LW, Smith JA. N-Alpha acetylation is required for normal growth and mating of Saccharomyces cerevisiae. J Bacteriol. 1989:171(11):5795-802.
49. Arnesen T, Gromyko D, Kagabo D, Betts MJ, Starheim KK, Varhaug JE, Anderson D, Lillehaug JR. A novel human NatA N-alpha-terminal acetyltransferase complex: hNaa16p-hNaa10p (hNat2-hArd1). BMC Biochem. 2009;10:15.

50. Arnesen T, Starheim KK, Van Damme P, Evjenth R, Dinh H, Betts MJ, Ryningen A, Vandekerckhove J, Gevaert K, Anderson D. The chaperonelike protein HYPK acts together with NatA in cotranslational N-terminal acetylation and prevention of Huntingtin aggregation. Mol Cell Biol. 2010;30(8):1898-909.

51. Sievers F, Wilm A, Dineen D, Gibson TJ, Karplus K, Li WZ, Lopez R, McWilliam $H$, Remmert $M$, Soding J, et al. Fast, scalable generation of highquality protein multiple sequence alignments using Clustal Omega. Mol Syst Biol. 2011;7:539.

52. Waterhouse AM, Procter JB, Martin DMA, Clamp M, Barton GJ. Jalview version 2-a multiple sequence alignment editor and analysis workbench. Bioinformatics. 2009;25(9):1189-91.
Ready to submit your research? Choose BMC and benefit from:

- fast, convenient online submission

- thorough peer review by experienced researchers in your field

- rapid publication on acceptance

- support for research data, including large and complex data types

- gold Open Access which fosters wider collaboration and increased citations

- maximum visibility for your research: over $100 \mathrm{M}$ website views per year

At BMC, research is always in progress.

Learn more biomedcentral.com/submissions 